\title{
HIV/AIDS prevalence cases among patient undergoing follow-up in federal teaching hospital Gombe state Nigeria application of multivariate analysis
}

\author{
İlker Etikan*, Kabiru Bala, Özgür Tosun, S Yavuz Sanisoğlu, Meliz Yuvalı and Savaş İlgi \\ Faculty of Medicine, Near East University, Near East Avenue, Postcode: 99138, Nicosia, North Cyprus, Mersin 10, Turkey
}

\begin{abstract}
The researcher in this write-up employed the use of multivariate statistical methods to find a more proactive solution to reduce and if possible to stop the rate of death as a result HIV/AIDS, so that with time it will be a history for patient leaving with HIV/AIDS in Teaching Hospital Gombe State and Nigeria in general. The powerful statistical softwares used in accessing the outcomes of this research is SPSS. This software helps the researcher in revealing those patients that were involved in relocating to other places, losing to follow up and those with incomplete attendance. 5000 sample of HIV/AIDS patient were randomly selected from the Hospital on antiretroviral therapy database to achieve this purpose. However from the sane investigation the end result revealed that there was significant difference between people living with the virus and people dying because of the virus. While the case of turnout from the record and during the follow-up, showed a higher percentage of people leading with virus comes from females, married people and younger age after taking statistics. However, several individuals from different region dying with the virus, is as a result of negative belief about the virus and obstruction of rules and regulation of taking drugs. This upsetting problem encouraged the researcher to recommend to the Government and Non-Governmental body to take immediate action in tackling this issue, so that it should be be-young reduction, but to stop the feature coming up generation with contamination of the virus.
\end{abstract}

\section{Introduction}

It is widely accepted that the virus started around 1920 in Kinshasa, Democratic Republic of Congo. Then the virus has crossed species from chimpanzee to human, but unusual incidents of the virus were recorded in previous 1970s. Despite the sign and symptoms recognized about the virus in 1980s, realizing about the course of transmission was the problem, until when the virus affected so many people $[1,2]$.

Various studies have concurred that presently Sub-Saharan Africa dominated the part of the world by toping and broken to be the highest with the history of the epidemic [3-5]. Following studies have disclosed that the detection of Human Immunodeficiency Virus (HIV) in 1980 became a worldwide disease in town that course harm to the immune system of the body that taking several lives of million people based on estimated were living with HIV around the world [6-8]. Gilmore \& Somerville have revealed that several human rights advocates stood up on the growing concerns of stigmatization and discrimination for those people living with HIV/AIDS in the world, because negativity is seriously affecting the well-being of infected individuals. This virus became a global issue to all regions because no region is safe, since almost all the countries have undergone through the incidents. Victims of HIV were facing serious challenges because it rapidly strikes the immune system by causing a serious harm to the body [9-12]. However, since the existence of the epidemic people with the virus were susceptible to the danger of developing serious infections and various other complications. The virus normally exists in semen, moisture in the rectum and blood. The only way of detecting it is by conducting a blood test, it can reveal if a person is HIV positive, when it is positive then one can get active antiretroviral therapy (HAART) to start the treatment process of HIV. According to the research by AA Awofala, it reveals some means of becoming a victim is through the course of insecure anal, vaginal and oral sex, by sharing of injecting or razor blade and mother transferring to her baby during pregnancy or in the course of breastfeeding [13]. Also, Homosexual sex and via intravenous drug injection in developed countries were the usual source of transmission of the virus, at the same time heterosexual contact in developing countries is another major course of transmission. Ilker Etikan, (2019) and Patrick S. Sullivan, (2012) both disclosed that currently the unique nature of the disease made it not to be easy in succeeding the advance medication that will completely cure the disease, it is only to reduce the infection rate but not completely to remedy people with the epidemic $[14,15]$. The cure would not wipe out totally the virus but sticking to the right treatment and care, patient with virus may live a longer and healthy life.

\section{Significance of the study}

Based on the previous research study, the introduction of ART brought about great improvement in reducing people living with the virus in Gombe State Federal Teaching Hospital and Nigeria at large. It also revealed that there was a reduction in deaths concerning this

${ }^{*}$ Correspondence to: İlker Etikan, Faculty of Medicine, Near East University, Near East Avenue, Postcode: 99138, Nicosia, North Cyprus, Mersin 10, Turkey, E-Mail: ilker.etikan@neu.edu.tr

Key words: highly active antiretroviral therapy, people living with hiv/aids, world health organization, non-governmental organization, federal teaching hospital gombe state

Received: February 06, 2019; Accepted: March 04, 2019; Published: March 11, 2019 

analysis

deadly disease. This prompted the researcher to find out if really the rate of dying with HIV/AIDS has reduced, so that the outcomes of the results will assist the researcher to advice the hospital and the Government on which next step to take in talking the virus.

\section{Acknowledgement}

We acknowledge both the Staff and Patient of Federal Teaching Hospital Gombe State for their voluntary involvement in this research study.

\section{Ethics}

The research study was performed on Patient receiving ART in Federal Teaching Hospital Gombe State with the permission and approval of the ethics committee of the Federal Teaching Hospital.

\section{Method}

The research study was limited to only 5000 sample of patient selected from ART unit in Gombe State Teaching Hospital, Gombe Nigeria. Statistical Package for the Social Science (SPSS) makes it possible for the analysis to be real from all the table result of analysis.

\section{Statement of the problem}

Rate of HIV/AIDS became a global issue for the past decades, presently youth and women were leading in the virus infection rate. As a result, the researcher observed it as a hindrance to find out the outcome of the prevalent using multivariate statistical methods so that powerful lasting solution to minimize and control the spreading of this virus.

The misfortune of this investigation from Nigerians: All the results of analysis explained during this study, there was less effect compared to what the researcher realizes during the conduct of this research, concerning the attitudes of Nigerians towards spreading of HIV virus to individuals. This attitude will be described as follows:

Hard less mentality from Africans: Citizens in Africa especially Nigerians are very wicked, heartless and without God fearing mind, those concerned with this attitude knowingly they are living with the virus, instead of reducing or stopping the spread of this virus but rather they are those responsible for the increasing rate of the epidemic, by using their available mechanism, this mechanism could be money, power and strength or force. Those in position of power or money use their position to have unprotected sex with individuals by giving them money or job, even though poverty is also the contributing factors to the victims, while those with strength forces or rape individuals to have unprotected sex with them, as a result they distribute the virus to them without minding the effects of the consequences.

Implications of death from the victims on therapy: The major cause of death due to HIV/AIDS nowadays is not the virus itself, rather from the patient coupling with negligence of some other factors. During the conduct of this investigation, it revealed that any patient that passes away because of the virus chooses to die on his own but not the virus that ends the patient life. Some of these factors that take lives of patient leaving with the virus are as follows;

Recurrent event: The victims living with the virus does not take care, treat or control any new foreign diseases that enter their body. The added or compounded sickness joint with the virus, if care is not taken and followed with proper management, it will deteriorate the body condition because the therapy only works on immune system, not to cure any foreign disease in the patient body, the early the better, the patient is suffering from headache, typhoid, malaria, any disorder in the system, the earlier to address it, to save the body system, because lack of taking care of any recurrent diseases in the body will worsen the situation, or collapsed the body system. The handling of foreign disease makes the retroviral therapy to be more effective in controlling the body immune system.

Misleading from our Religion Leaders: Our Imams and Pastors convince patients with HIV/AIDS that prayers will completely heal AIDS. Based on the confidence imposed on the patient, they foolishly stop taking their retroviral therapy, until at the end, when the situation is too late, due to the stoppage, because worst condition has happened, at that stage no amount of help or assistance will bring back the patient natural life.

Traditional herbalist believes: Patient compliance with traditional herbalist become a victim, by discontinuing or changing the pattern of taking their drugs, accepting this traditional medicine from herbalist before you know, patient condition will be critical due to the traditional medicine been consumed while the virus will gain more strength in few time, to destroy all the cells in the human body. With time the patient will be helpless, his relative must convey him to the hospital or place of follow-up, if he is lucky, he will be managing at AIDS level before death.

Table 1 Statistics from the Kruskal Wallis test showed a significant difference between age among gender $(\mathrm{p}=0.000)$. The Chi-Square result for marital status with gender showed there was association between them $(\mathrm{p}=0.000)$. Also, age with marital status from Kruskal Wallis reveal a significant difference between age among marital status $(\mathrm{p}=0.000)$. There was an association between age category with gender from cross tabulation result $(\mathrm{p}=0.000)$. There was also a significant difference between age among age category from Kruskal Wallis test $(\mathrm{p}=0.000)$

The above Table 2 outcome showed that age was significant on the patient receiving ART $(\mathrm{OR}=0.921,95 \% \mathrm{CI}=0.912-0.931)$. Statistical significance was seen in divorce and widow from the marital status, for divorce it is $(\mathrm{OR}=54.798,95 \% \mathrm{CI}=13.031-230.442)$, while for widow it is $(\mathrm{OR}=22.325,95 \% \mathrm{CI}=11.789-42.277)$. Statistical significance was seen from age group 13 - 22 (OR:11.351, 95\% CI=5.927-21.738), group 23-32 $(\mathrm{OR}=6.525,95 \% \mathrm{CI}=4.157-10.242)$ and from age group 33-42 $(\mathrm{OR}=2.136,95 \% \mathrm{CI}=1.369-3.331)$ respectively. Statistical significance was seen from occupations of housewife as $(\mathrm{OR}=11.389,95 \% \mathrm{CI}=2.155$ 60.182 ) and last there was statistical significance revealed in month of October and November from last month of visit (OR=0.360 95\% $\mathrm{CI}=0.172-0.754)$ from October while $(\mathrm{OR}=0.425,95 \% \mathrm{CI}=0.202-0.895)$ from month of November.

The above Table 3 from age group with ref 53 and above showed that age group 13-23 proved significant from all marital status, as such marital status for divorced gave $(\mathrm{OR}=0.071,95 \% \mathrm{CI}=0.024-0.210)$, those that were married gave $(\mathrm{OR}=0.074,95 \% \mathrm{CI}=0.035-0.156)$ and those from widow presented as $(\mathrm{OR}=0.084,95 \% \mathrm{CI}=0.033-0.209)$. Correspondingly this was statistically significant in age group 23-32 for divorced as $(\mathrm{OR}=0.159,95 \% \mathrm{CI}=0.063-0.401)$, married as $(\mathrm{OR}=0.193$, 95\% $\mathrm{CI}=0.094-0.395)$ and widow $(\mathrm{OR}=0.234,95 \% \mathrm{CI}=0.103-0.523)$ respectively. Age group 33-42 indicates statistically significance in marital status of divorced $(\mathrm{OR}=0.19095 \% \mathrm{CI}=0.074-0.489)$, married as $(\mathrm{OR}=0.311,95 \% \mathrm{CI}=0.150-0.642)$ and from widow as $(\mathrm{OR}=0.287,95 \%$ $\mathrm{CI}=0.125-0.660)$ respectively. In addition, age category of 43-52 reveal that, there was statistical significance from marital status of divorced as $(\mathrm{p}=0.010, \mathrm{OR}=0.271,95 \% \mathrm{CI}=0.100-0.733)$ and married as $(\mathrm{p}=0.019$, $\mathrm{OR}=0.406,95 \% \mathrm{CI}=0.191-0.861$. Finally, from hospital patient status from Taraba state revealed that death status was significant. From the 
Etikan İ (2019) HIV/AIDS prevalence cases among patient undergoing follow-up in federal teaching hospital Gombe state Nigeria application of multivariate analysis

Table 1. Chi-Square, Descriptive Statistics, Mann Whitney test and Kruskal Wallis test

\begin{tabular}{|c|c|c|c|c|c|c|}
\hline \multirow{2}{*}{ Variables } & \multicolumn{2}{|c|}{ Chi-Square count } & \multirow{2}{*}{$\begin{array}{l}\text { Frequency } \\
\text { (N) }\end{array}$} & \multirow{2}{*}{$\begin{array}{l}\text { Percentage } \\
(\%)\end{array}$} & \multirow{2}{*}{$\begin{array}{c}\text { Chi-Square \& } \\
\text { p-value }\end{array}$} & \multirow{2}{*}{$\begin{array}{c}\text { Mann Whitney \& } \\
\text { Kruskal Wallis p-value }\end{array}$} \\
\hline & Male & Female & & & & \\
\hline \multicolumn{7}{|c|}{ Gender } \\
\hline Male & & & 1647 & 31.7 & & \multirow{2}{*}{$\mathrm{p}=0.000$} \\
\hline Female & & & 3349 & 64.4 & & \\
\hline \multicolumn{7}{|c|}{ CD4 count } \\
\hline Yes & 82 & 187 & 269 & 5.2 & \multirow{2}{*}{$\mathrm{p}=0.372$} & \multirow{2}{*}{$\mathrm{p}=0.940$} \\
\hline No & 1565 & 3161 & 4730 & 91.0 & & \\
\hline \multicolumn{7}{|c|}{ Chemistry } \\
\hline Yes & 72 & 157 & 229 & 4.4 & \multirow{2}{*}{$\mathrm{p}=0.614$} & \multirow{2}{*}{$\mathrm{p}=0.901$} \\
\hline No & 1575 & 3191 & 4770 & 91.7 & & \\
\hline \multicolumn{7}{|c|}{ Haematology } \\
\hline Yes & 69 & 155 & 224 & 4.3 & \multirow{2}{*}{$\mathrm{p}=0.480$} & \multirow{2}{*}{$\mathrm{p}=0.580$} \\
\hline No & 15728 & 3193 & 4775 & 91.8 & & \\
\hline \multicolumn{7}{|c|}{ Hospital status } \\
\hline Alive & 1580 & 2313 & 4797 & 92.3 & \multirow{3}{*}{$\mathrm{p}=0.916$} & \multirow{3}{*}{$\mathrm{p}=0.087$} \\
\hline Death & 27 & 59 & 86 & 1.7 & & \\
\hline Transfer & 40 & 77 & 117 & 2.3 & & \\
\hline \multicolumn{7}{|c|}{ Marital status } \\
\hline Divorce & 2 & 188 & 190 & 3.7 & \multirow{4}{*}{$\mathrm{p}=0.000$} & \multirow{4}{*}{$\mathrm{p}=0.000$} \\
\hline Married & 1361 & 2158 & 3523 & 67.8 & & \\
\hline Widow & 19 & 517 & 536 & 10.3 & & \\
\hline Single & 253 & 472 & 725 & 13.9 & & \\
\hline \multicolumn{7}{|c|}{ Age category } \\
\hline $13-22$ & 48 & 249 & 297 & 5.7 & \multirow{5}{*}{$\mathrm{p}=0.000$} & \multirow{5}{*}{$\mathrm{p}=0.000$} \\
\hline $23-32$ & 389 & 1659 & 2049 & 39.4 & & \\
\hline $33-42$ & 701 & 970 & 1674 & 32.2 & & \\
\hline $43-52$ & 393 & 369 & 762 & 14.7 & & \\
\hline 53 above & 115 & 94 & 209 & 4.0 & & \\
\hline \multicolumn{7}{|c|}{ Patient state of visit } \\
\hline Gombe & 981 & 2024 & 3008 & 57.8 & & \\
\hline Bauchi & 106 & 209 & 315 & 6.1 & & \\
\hline Yobe & 60 & 97 & 157 & 3.0 & & \\
\hline Borno & 42 & 60 & 102 & 2.0 & $\mathrm{p}=7.788$ & $\mathrm{p}=0.107$ \\
\hline Adamawa & 55 & 138 & 193 & 3.7 & & \\
\hline Taraba & 20 & 51 & 71 & 1.4 & & \\
\hline Others & 24 & 51 & 75 & 1.4 & & \\
\hline
\end{tabular}

Table 2. Logistic Regression

\begin{tabular}{|c|c|c|c|c|c|}
\hline \multirow{2}{*}{ Variable } & \multirow{2}{*}{$\beta$} & \multirow{2}{*}{ p-value } & \multirow{2}{*}{$\operatorname{Exp}(\beta)$} & \multicolumn{2}{|c|}{ 95\% CI for $\operatorname{Exp}(\beta)$} \\
\hline & & & & Lower & Upper \\
\hline Age & -0.082 & 0.000 & 0.921 & 0.912 & 0.931 \\
\hline \multicolumn{6}{|c|}{ CD4 (baseline Yes) } \\
\hline No & -0.057 & 0.907 & 0.945 & 0.363 & 2.456 \\
\hline \multicolumn{6}{|c|}{ Haematology (baseline Yes) } \\
\hline No & 0.283 & 0.680 & 1.327 & 0.346 & 5.079 \\
\hline \multicolumn{6}{|c|}{ Chemistry (baseline Yes) } \\
\hline No & 0.055 & 0.935 & 1.057 & 0.282 & 3.964 \\
\hline \multicolumn{6}{|c|}{ Hospital status (baseline transfer) } \\
\hline Live & -0.090 & 0.769 & 0.914 & 0.500 & 1.668 \\
\hline Death & -0.453 & 0.319 & 0.636 & 0.261 & 1.550 \\
\hline \multicolumn{6}{|c|}{ Marital status (baseline single) } \\
\hline Divorce & 4.004 & 0.000 & 54.798 & 13.031 & 230.442 \\
\hline Married & -0.238 & 0.078 & 0.788 & 0.605 & 1.027 \\
\hline Widow & 3.106 & 0.000 & 22.325 & 11.789 & 42.277 \\
\hline \multicolumn{6}{|c|}{ Age category (baseline 53 above) } \\
\hline $13-22$ & 2.429 & 0.000 & 11.351 & 5.927 & 21.738 \\
\hline $23-32$ & 1.876 & 0.000 & 6.525 & 4.157 & 10.242 \\
\hline $33-42$ & 0.759 & 0.001 & 2.136 & 1.369 & 3.331 \\
\hline $43-52$ & 0.166 & 0.485 & 1.181 & 0.740 & 1.884 \\
\hline
\end{tabular}


Etikan İ (2019) HIV/AIDS prevalence cases among patient undergoing follow-up in federal teaching hospital Gombe state Nigeria application of multivariate analysis

\begin{tabular}{|c|c|c|c|c|c|}
\hline \multirow{2}{*}{ Variable } & \multirow{2}{*}{$\beta$} & \multirow{2}{*}{ p-value } & \multirow{2}{*}{$\operatorname{Exp}(\beta)$} & \multicolumn{2}{|c|}{ 95\% CI for $\operatorname{Exp}(\beta)$} \\
\hline & & & & Lower & Upper \\
\hline \multicolumn{6}{|c|}{ State (baseline others) } \\
\hline Gombe & -0.250 & 0.464 & 0.799 & 0.399 & 1.521 \\
\hline Bauchi & -0.268 & 0.471 & 0.765 & 0.369 & 1.585 \\
\hline Yobe & -0.375 & 0.354 & 0.687 & 0.311 & 1.519 \\
\hline Maiduguri & -0.620 & 0.163 & 0.538 & 0.225 & 1.285 \\
\hline Adamawa & -0.218 & 0.583 & 0.804 & 0.369 & 1.750 \\
\hline Taraba & -0.119 & 0.808 & 0.888 & 0.341 & 2.315 \\
\hline \multicolumn{6}{|c|}{ Quarter month of last visit (baseline Q4) } \\
\hline $1^{\text {st }}$ Quarter & -0.593 & 0.096 & 0.552 & 0.275 & 1.112 \\
\hline $2^{\text {nd }}$ Quarter & -0.355 & 0.328 & 0.701 & 0.344 & 1.427 \\
\hline $3^{\text {rd }}$ Quarter & -0.555 & 0.133 & 0.574 & 0.279 & 1.183 \\
\hline \multicolumn{6}{|c|}{ Quarter month ofnext visit (baseline Q4) } \\
\hline $1^{\text {st }}$ Quarter & 0.207 & 0.524 & 1.230 & 0.650 & 2.329 \\
\hline $2^{\text {nd }}$ Quarter & -0.116 & 0.734 & 0.891 & 0.456 & 1.738 \\
\hline $3^{\text {rd }}$ Quarter & -0.221 & 0.458 & 0.802 & 0.447 & 1.438 \\
\hline \multicolumn{6}{|c|}{ Occupation (baseline others 13) } \\
\hline Student & 0.236 & 0.781 & 1.266 & 0.240 & 6.690 \\
\hline Civil servant & 0.572 & 0.493 & 1.771 & 0.345 & 9.086 \\
\hline House wife & 2.433 & 0.004 & 11.389 & 2.155 & 60.182 \\
\hline Private & 0.824 & 0.368 & 2.281 & 0.379 & 13.708 \\
\hline Business & 0.362 & 0.668 & 1.437 & 0.274 & 7.531 \\
\hline Health personnel & 0.634 & 0.497 & 1.886 & 0.302 & 11.772 \\
\hline Military and para military & 0.310 & 0.720 & 1.363 & 0.250 & 7.432 \\
\hline Hand work & -0.496 & 0.571 & 0.609 & 0.110 & 3.384 \\
\hline Teacher & 0.970 & 0.274 & 2.637 & 0.464 & 14.991 \\
\hline Retiree & 1.239 & 0.173 & 3.452 & 0.580 & 20.545 \\
\hline Farmer & -0.868 & 0.318 & 0.420 & 0.076 & 2.304 \\
\hline Banker & -0.565 & 0.612 & 0.568 & 0.064 & 5.057 \\
\hline \multicolumn{6}{|c|}{ Month of last visit (baseline December) } \\
\hline January & 0.255 & 0.415 & 1.291 & 0.699 & 2.385 \\
\hline February & 0.122 & 0.703 & 1.130 & 0.603 & 2.117 \\
\hline April & -0.245 & 0.400 & 0.783 & 0.442 & 1.385 \\
\hline May & -0.228 & 0.332 & 0.796 & 0.502 & 1.262 \\
\hline July & -0.413 & 0.152 & 0.662 & 0.376 & 1.164 \\
\hline August & -0.180 & 0.539 & 0.836 & 0.471 & 1.481 \\
\hline October & -1.021 & 0.007 & 0.360 & 0.172 & 0.754 \\
\hline November & -0.856 & 0.024 & 0.425 & 0.202 & 0.895 \\
\hline \multicolumn{6}{|c|}{ Month of next visit (baseline December) } \\
\hline January & -0.393 & 0.210 & 0.675 & 0.366 & 1.247 \\
\hline February & -0.019 & 0.952 & 0.981 & 0.530 & 1.817 \\
\hline April & 0.047 & 0.887 & 1.048 & 0.546 & 2.014 \\
\hline May & -0.288 & 0.392 & 0.750 & 0.388 & 1.451 \\
\hline July & -0.124 & 0.661 & 0.883 & 0.507 & 1.539 \\
\hline August & 0.029 & 0.908 & 1.030 & 0.627 & 1.691 \\
\hline October & -0.256 & 0.385 & 0.774 & 0.435 & 1.378 \\
\hline November & 0.091 & 0.756 & 1.096 & 0.616 & 1.949 \\
\hline
\end{tabular}

remaining state it was $(\mathrm{OR}=8.265 \mathrm{E}-10,95 \% \mathrm{CI}=8.265 \mathrm{E}-10-8.265 \mathrm{E}$ $=10$ ).

\section{Summary}

As it was seen that ART follow-up plays a significant improvement for patient leaving with HIV/AIDS, also most of the region, tribe and individual were committed to their follow-up. Base on this result both the gender was recommended to be devoted with follow-up so that there will be reduction or if possible, bring a solution to end the spread of the virus. Individual should provide a habit of knowing their status so that compliance of taking drugs immediately will commence. People should stop any sort of stigmatization for patient living with the virus.
The management staffs, nurses, doctors and other personnel should be more tolerant and understanding with their patient. Government should provide another channel of circulating information about the prevalence of HIV, especially on those dangerous individuals by making use of Ministry of Education in school, so that serious conditions like the HIV to be included in the curriculum system of Nigerian Education. More so teachers should be used as a mechanism for massive promotion of information about regular check-up and safe sex to tackle the increasing rate of the virus. There is also need to include the mobilization of community Elders, Village Head and Political Elite because they played important role in any community setup, with their influence the spread of the virus in our Dear country 
Etikan İ (2019) HIV/AIDS prevalence cases among patient undergoing follow-up in federal teaching hospital Gombe state Nigeria application of multivariate analysis

Table 3. Multinomial Logistic Regression

\begin{tabular}{|c|c|c|c|c|c|}
\hline \multirow{2}{*}{ Variable } & \multirow{2}{*}{$\beta$} & \multirow{2}{*}{$p$-value } & \multirow{2}{*}{$\operatorname{Exp}(\beta)$} & \multicolumn{2}{|c|}{$95 \%$ CI for $\beta$} \\
\hline & & & & Lower & Upper \\
\hline \multicolumn{6}{|c|}{ age category (13-23 ref 53+) and marital status (ref single) } \\
\hline Divorce & -2.652 & 0.000 & 0.071 & 0.024 & 0.210 \\
\hline Married & -2.609 & 0.000 & 0.074 & 0.035 & 0.156 \\
\hline Widow & -2.482 & 0.000 & 0.084 & 0.033 & 0.209 \\
\hline \multicolumn{6}{|c|}{ age category (23-32 ref 53+) and marital status (ref single) } \\
\hline Divorce & -1.839 & 0.000 & 0.159 & 0.063 & 0.401 \\
\hline Married & -1.647 & 0.000 & 0.193 & 0.094 & 0.395 \\
\hline Widow & -1.453 & 0.001 & 0.234 & 0.103 & 0.532 \\
\hline \multicolumn{6}{|c|}{ age category (33-42 ref 53+) and marital status (ref single) } \\
\hline Divorce & -1.658 & 0.001 & 0.190 & 0.074 & 0.489 \\
\hline Married & -1.168 & 0.002 & 0.311 & 0.150 & 0.642 \\
\hline Widow & -1.247 & 0.003 & 0.287 & 0.125 & 0.660 \\
\hline \multicolumn{6}{|c|}{ age category (43-52 ref 53+) and marital status (ref single) } \\
\hline Divorce & -1.307 & 0.010 & 0.271 & 0.100 & 0.733 \\
\hline Married & -0.902 & 0.019 & 0.406 & 0.191 & 0.861 \\
\hline Widow & -0.813 & 0.065 & 0.444 & 0.187 & 1.053 \\
\hline \multicolumn{6}{|c|}{ age category (13-22 ref 53 and above) hospital Status (ref transfer) } \\
\hline Alive & 0.652 & 0.234 & 1.919 & 0.656 & 5.617 \\
\hline Death & 0.981 & 0.270 & 2.667 & 0.466 & 15.252 \\
\hline \multicolumn{6}{|c|}{ age category (23-32 ref 53 and above) hospital Status (ref transfer) } \\
\hline Alive & 0.568 & 0.146 & 1.765 & 0.821 & 3.798 \\
\hline Death & 0.812 & 0.254 & 2.252 & 0.558 & 9.090 \\
\hline \multicolumn{6}{|c|}{ age category (33-42 ref 53 and above) hospital Status (ref transfer) } \\
\hline Alive & 0.620 & 0.120 & 1.859 & 0.850 & 4.063 \\
\hline Death & 0.793 & 0.272 & 2.210 & 0.537 & 9.098 \\
\hline \multicolumn{6}{|c|}{ age category (43-52 ref 53 and above) hospital Status (ref transfer) } \\
\hline Alive & 0.249 & 0.552 & 1.282 & 0.565 & 2.911 \\
\hline Death & 0.043 & 0.957 & 1.043 & 0.225 & 4.840 \\
\hline \multicolumn{6}{|c|}{ state of visit (Gombe: ref other ) and hospital status (ref transfer) } \\
\hline Alive & -0.573 & 0.572 & 0.564 & 0.077 & 4.114 \\
\hline Death & 1.688 & 0.136 & 0.185 & 0.020 & 1.702 \\
\hline \multicolumn{6}{|c|}{ State of visit (Bauchi: ref other ) and hospital status (ref transfer) } \\
\hline Alive & -0.618 & 0.563 & 0.539 & 0.066 & 4.382 \\
\hline Death & -1.856 & 0.139 & 0.156 & 0.013 & 1.828 \\
\hline \multicolumn{6}{|c|}{ State of visit (Yobe: ref other ) and hospital status (ref transfer) } \\
\hline Alive & -0.330 & 0.777 & 0.719 & 0.073 & 7.036 \\
\hline Death & -1.386 & 0.317 & 0.250 & 0.017 & 3.770 \\
\hline \multicolumn{6}{|c|}{ state of visit (Maiduguri: ref other ) and hospital status (ref transfer) } \\
\hline Alive & -1.707 & 0.343 & 0.343 & 0.038 & 3.134 \\
\hline Death & -2.079 & 0.141 & 0.125 & 0.008 & 1.998 \\
\hline \multicolumn{6}{|c|}{ state of visit (Adamawa: ref other ) and hospital status (ref transfer) } \\
\hline Alive & -0.643 & 0.560 & 0.526 & 0.060 & 4.580 \\
\hline Death & -1.609 & 0.217 & 0.200 & 0.016 & 2.575 \\
\hline \multicolumn{6}{|c|}{ state of visit (Taraba: ref other ) and hospital status (ref transfer) } \\
\hline Alive & -0.708 & 0.567 & 0.493 & 0.044 & 5.561 \\
\hline Death & -20.914 & 0.000 & $8.265 \mathrm{E}-10$ & $8.265 \mathrm{E}-10$ & $8.265 \mathrm{E}-10$ \\
\hline
\end{tabular}

will be reduced and will prevent the feature coming up generation from infection of this virus.

\section{References}

1. Onakewhor JUE, Okonofua FE (2009) The Prevalence of Dual Human Immunodeficiency Virus/Hepatitis C Virus (HIV/HCV) Infection in Asymptomatic Pregnant Women in Benin City, Nigeria.

2. HIV/AIDS Public Health Campaigns in Italy. Accessed from www.who.int/hiv/ mediacentre/2006.

3. AIDS epidemic update, December. Accessed from www.who.int/hiv/mediacentre/2006.

4. Beegl K, Walque D (2009) Demographic and Socioeconomic Patterns of HIV/AIDS Prevalence in Africa, Development Research Group, World Bank, Washington DC, USA.
5. Armstrong-Mensah E, Ramsey-White K, Pavao CAO, McCool S, Bohannon K (2017) HIV/AIDS Prevention: Reducing Social Stigma to Facilitate Prevention in the Developing World. Madridge J AIDS 2: 12-16.

6. Harry H, Panjer D (1988) AIDS: survival analysis of persons testing HIV+. Transact Soc Actuar J 40: 1.

7. Shibre MB (2014) Survival in HIV-Infected Patient after Initiation of HAART in Zewditu Memorial Hospital, Addis Ababa, Ethiopia.

8. Carvour ML, Harms JP, Lynch CF, Mayer RR, Meier JL, et al, (2015) Differentia Survival for Men and Women with HIV/AIDS-Related Neurologic Diagnoses. Plos One 10: e0123119.

9. Gilmore N, Somerville MA (1994) Stigmatization, scapegoating and discrimination in sexually transmitted diseases: overcoming 'them' and 'us'. Soc Sci Med 39: 1339-1358. [Crossref] 
Etikan İ (2019) HIV/AIDS prevalence cases among patient undergoing follow-up in federal teaching hospital Gombe state Nigeria application of multivariate analysis

10. Levy J (1993) Pathogenesis of Human Immunodeficiency Virus Infection. Microbiol Rev 57: 183-289. [Crossref]

11. Fauci A (1988) The Human Immunodeficiency Virus, Infectivity and Mechanisms of Pathogenesis. Science 5: 617-622. [Crossref]

12. Edwin JB, Derek T (2008) HIV treatment update.
13. Awoyemi AA (2016) Epidemiology, HIV/AIDS in Nigeria. King Saud University, Saudi Arabia.

14. Sullivan PS (2012) Successes and challenges of HIV prevention in men who have sex with men. Lancet 380: 388-399.

15. Ilker Etikan, Kabiru B, Meliz Y (2009) Application of Multivariate Statistical Methods of Patient Surviving ART Follow-up. Annals Biostat Biomet App 9: 12.

Copyright: (O2019 Etikan İ. This is an open-access article distributed under the terms of the Creative Commons Attribution License, which permits unrestricted use, distribution, and reproduction in any medium, provided the original author and source are credited. 